\title{
JIA pathogenesis - genetics
}

Wendy Thomson

From 21st European Pediatric Rheumatology (PReS) Congress

Belgrade, Serbia. 17-21 September 2014

Juvenile Idiopathic Arthritis is a heterogeneous disease with significant variability in long-term outcome and treatment response; this occurs both between and within JIA subtypes, as defined by the current International League Against Rheumatism (ILAR) classification. There are currently no robust clinical or biological predictors of outcome or treatment response in JIA. Given that JIA is a complex genetic disorder, genetic studies provide an opportunity to address this issue, and whilst previous studies have often been limited by statistical power to identify the likely modest effect sizes, the recent establishment of a number of international consortia for JIA genetics has allowed this issue to be resolved.

This presentation will summarize the current understanding of the genetic basis of JIA susceptibility, prognosis and treatment response and will describe how these genetic associations may further our understanding of the molecular mechanisms and immunological pathways involved in this disease. In addition it will provide insights into how we might utilise this data to progress towards the ultimate goals of predicting longterm disease outcomes at onset, predicting drug response, and move towards more targeted treatment options for children with JIA.

\section{Disclosure of interest}

None declared.

Published: 17 September 2014

doi:10.1186/1546-0096-12-S1-I2

Cite this article as: Thomson: JA pathogenesis - genetics. Pediatric

Rheumatology 2014 12(Suppl 1):12.

Submit your next manuscript to BioMed Central and take full advantage of:

- Convenient online submission

- Thorough peer review

- No space constraints or color figure charges

- Immediate publication on acceptance

- Inclusion in PubMed, CAS, Scopus and Google Scholar

- Research which is freely available for redistribution
C Biomed Central

(0) 2014 Thomson; licensee BioMed Central Ltd. This is an Open Access article distributed under the terms of the Creative Commons Attribution License (http://creativecommons.org/licenses/by/4.0), which permits unrestricted use, distribution, and reproduction in any medium, provided the original work is properly cited. The Creative Commons Public Domain Dedication waiver (http://creativecommons.org/publicdomain/zero/1.0/) applies to the data made available in this article, unless otherwise stated. 